\title{
THE CONCEPT OF "SECURITY" IN ANNUAL SPEECHES OF THE REPUBLIC OF POLAND MINISTERS OF FOREIGN AFFAIRS AFTER 2001
}

The purpose of the publication is to present how the concept of security has been defined in annual speeches of Poland's foreign ministers after the 9/11 attacks in 2001. Research problem: the impact of the international situation on ways of ensuring Poland's security in the annual speeches of Polish foreign ministers. Apart from the aspect of classically understood security, the analysis also covers modern categories of security that is economic, public, ecological, energy or food security. The temporal range is from 2001 to 2017. Following the definition in the Polish Language Dictionary published by PWN I define "security" as "the state of non-threat" (Bezpieczeństwo, 2017).

$* * *$

Every year foreign ministers of Poland give their annual speeches - officially known as the Information of the Foreign Minister on the goals of foreign policy, in which they define priorities, characterize challenges, and present corrections to the policy. Sometimes it is just an ordinary fulfilment of the obligation, which does not provoke greater conflicts or reflections and is presented in the nearly empty hall, but since 2010, after the plane crash near Smolensk, there have been very exciting debates connected with disputes in the Parliament (speeches given by Radosław Sikorski between 2011-2014), also in connection to responsibility for state security. The speeches which were urgent responses to events in the world (Sikorski, 2014) and the ones that were given when new governments came to power: (Cimoszewicz, 2002; Meller, 2006; Sikorski, 2008; Sikorski, 2012; Waszczykowski, 2016) will be particularly relevant to the search for answers to the research problem because apart from presenting current issues the ministers were obliged to discuss four-year foreign policy assumptions. In terms of widely understood security they will be useful to determine stages of its achievement or measures to maintain security and emphasize the attitude to guaranteeing the security of Poland. In the Polish legal system, the direct task of the foreign minister related to security - explicitly stated, not in the intention of conducting foreign policy and presenting multiannual strategies which should aim at reaching security, is to coordinate the activities that provide safety to diplomatic missions (Ustawa, 1997: Art. 32.4).

With the end of the "Cold War" and the breakdown of the two-block system, the concept of security was re-evaluated (Buzan, 1997; Waltz, 2000; Koziej, 2011). In 
the 1990s the creation or correction of a new world order could be seen. One element of the new order was the enlargement of NATO, first with the states of Central Europe and then in the $21^{\text {st }}$ century the states of Southern and Eastern Europe. A larger number of member states did not mean an increase in the military and defence capabilities, as rather small and militarily weak states joined in, and the majority of the "old" members significantly reduced military budgets and thus their combat capabilities, and France has even remained outside the military structure since 2009. However, there was a strong belief in the military power of the US which as many thought, spent enough to be able to defend everyone. Despite that, for Poland NATO membership was an existential matter. Poland wanted to avoid the fate of the "seasonal state", the term used in Germany to describe the Second Republic of Poland during the interwar period.

A sense of security in Europe also increased after the Maastricht Treaty and the gradual incorporation of other states to the UE, first Austria, Sweden and Finland - which until the early 1990s had limited foreign policy capabilities due to pressure from the USSR, and later 13 Central and Eastern European countries, including Poland. Poland played a special role, because for the two organizations Poland's accession involved accepting the burden of reforming the largest army among new NATO members and reforming the largest economy of the most populous state among new EU members. The geostrategic factor was also significant - "moving" the West to Central Europe, interfering in the traditional Russia's zone of influence, and for the states of the region protecting them against possible Russian expansion. Poland's accession to the two organisations also increased opportunities for energy or environmental security - the theoretical possibility of cooperation and creation of projects connected with pipelines and gas pipelines, the acquisition of the EU funds. On the other hand, however, it involved engaging in NATO military intervention in Afghanistan or in the war in Iraq, which in turn threatened public security in Poland. ${ }^{1}$

\section{"SECURITY" IN ANNUAL SPEECHES BETWEEN 2001-2005}

In 2001 Poland was already a member of NATO, and was negotiating conditions for joining the EU. It was the last year of then-minority government formed by the Solidarity Electoral Action party and the Polish political scene awaited the expected reorientation and victory of post-communists from the Democratic Left Alliance (SLD). Three months before the attacks on the WTC Minister Władysław Bartoszewski addressed the issue of security in a very detailed way. He emphasized Poland's presence in NATO, owing to which "Poland is included into the sphere of stability in the field of security policy" (Bartoszewski, 2001) as well as the need to assume greater responsibility (within NATO) and reform the army. He defined Poland's tasks related to international security: deep engagement in NATO activities, enlargement of the sphere

${ }^{1}$ Between 2003-2006 Al-Qaida planned to carry out some terrorist attacks in Poland. See: P. Pytlakowski, Terroryści za progiem, http://www.polityka.pl/tygodnikpolityka/kraj/1603307,1,polskiesluzby-udaremnily-atak-terrorystyczny.read (13.02.2017). 
of stability and security in Europe, support for the admission of new NATO members, involvement in the co-operation between NATO and Ukraine and NATO and Russia, and a "special place" in the development of the European Security and Defence Policy. ${ }^{2}$ Poland was to strive for clear rules of the NATO-EU relations, be active in the UN and OSCE to strengthen international security. In addition, Poland wanted to expand the relations with the US in the military sphere and increase the US involvement in Central and Eastern Europe (ibid.). This gives an image of a responsible foreign minister who wants to secure Poland's immediate surrounding and supports all initiatives and organizations that can help in it. At the same time he does not forget about stabilization in the world.

One should take into account the fact that there was some euphoria among the Polish elites after decades of functioning in the realities of the Warsaw Pact and in the fear of the USSR/Russian Federation. At that time in Poland NATO was regarded the only credible defence organization capable of defending Poland. Moreover, it should be remembered that Poland's national interest was the pursuit of allies in order not to be politically "alone" against the Russian Federation, which also resulted from the limited capacity of the medium-sized state (Lastawski, 2017: 47) located between two powers (Germany, Russia) with much greater potential. But what was more important, the USA was a NATO member, which allowed Poland to obtain the guarantee status for the protection of its borders, not through political promises or bilateral agreements, but supported by the symbolism of NATO's commitment to collective protection of the members - the well-known Article 5 (Traktat, 2014: 162-163).

The events on 11 September 2001 changed the international order, because as their consequence the USA made a number of decisions that directly and indirectly affected practically every country in the world. Military involvement in Afghanistan and Iraq also increased the presence of the US troops on several continents, and from the Polish perspective it shifted the main focus from Central and Eastern Europe for years. In this spirit Włodzimierz Cimoszewicz gave his three speeches (2002-2004). In his opinion the attacks in the USA "undermined the current model of international security and affected the condition of the world economy" (Cimoszewicz, 2002). The world, including Poland, officially began a war against terrorism. The minister regarded the 9/11 attack to be a blow against the civilization of the West, therefore the priority was to ensure to Poland security and the right place in the EU. Włodzimierz Cimoszewicz saw threats in the proliferation of mass destruction weapons, chemical and bacteriological weapons, and he opted for the reform of NATO that was not prepared for new challenges. In his opinion the security of Poland could be ensured by NATO and the creation of an anti-terrorist coalition with the USA. He assumed the leading role of NATO in its cooperation with the European Security and Defence Policy. The minister called for a review of Poland's current security strategy, and also counted on a greater efficiency of the OSCE. In the following years (Cimoszewicz, 2003; Cimoszewicz, 2004) he continued to see terrorism as the greatest security problem and considered the state security to be a priority. He was satisfied with the direction of NATO reform agreed at the Prague summit in November 2002 and the

\footnotetext{
${ }^{2}$ Further on it is abbreviated as ESDP.
} 
decision to enlarge the Alliance with Lithuania and Slovakia - Poland's neighbours, which would strengthen its security and its position in the structure. Another issue that is worth mentioning is the proliferation of mass destruction weapons. The minister discussed it to justify Poland's attitude to Iraq and the need for Iraq's response to the UN Security Council resolution as "Iraq's serious infringement of Resolution 1441 would require a firm response. Poland is ready to support it" (Cimoszewicz, 2003). There is no doubt that this was a kind of ideological support for Poland's invasion in Iraq. According to the minister Poland's involvement in Iraq was a chance for Poland's policy to go actively outside Europe. Besides, it brought a new look at global security (Cimoszewicz, 2004).

His successor, Adam Daniel Rotfeld, who was the deputy minister of Cimoszewicz (as undersecretary and secretary of state at the Ministry of Foreign Affairs) for four years, hoped that the new government and political system that was expected in Poland after the parliamentary elections in the autumn 2005 would continue the major directions of foreign policy related to the state security. Just like his predecessor Rotfeld supported changes in NATO and selective globalization of the Alliance's stabilization activities. However, he considered guarantees given by the US to be the basis of Poland's security and this was a unique thing that many states unsuccessfully sought for years. In the minister's opinion, Poland's position in Washington became stronger after the EU accession. He emphasized that Russia should be linked to Europe and NATO, which would create a desirable and suitable situation (including security) for both parties: the Western World, including Poland, and Russia. A very important factor was to postulate a change in the global international order and call for multilateralism, which would tackle the world problems: the proliferation of mass destruction weapons, asymmetric conflicts, falling countries and fallen states. The stronger and reformed UN would help to reach that goal. In this way Rotfeld referred to the idea of Włodzimierz Cimoszewicz, who proposed the New Political Act for the UN in 2002 which was to allow for the effective conversion of the static institution into the one that is able to react (cf. Informacja, 2002). He noted that 2005 was supposed to be a test for the reform capacity of the UN, but the reality of their implementation was left open (Rotfeld, 2005).

This ends the work of foreign ministers in the governments formed primarily by the Democratic Left Alliance (by Leszek Miller in 2001-2004 and Marek Belka 2004-2005). Their annual speeches corresponded to the changing international situation connected with the US implementation of Pax Americana (Barber, 2005: 33-160), in which Poland took an active part. The ministers perceived security in global and regional terms - primarily in the securitization of Poland, which had always been a priority. They called for joint responsibility for the international order, including military involvement in Afghanistan and especially in Iraq. Their work fell on an intensified period of combat missions of the USA and the allies (including Poland's active participation) and was also connected with attempts of political reorientation in Europe. The division into "old" and "new" Europe publicly proclaimed by the US Secretary of Defence Donald Rumsfeld put Poland in a troublesome position as a future EU member, but the creator of this concept praised "new Europe" for its commitment to the of world security (Rumsfeld, 2003). 


\section{"SECURITY" IN ANNUAL SPEECHES BETWEEN 2006-2007}

At the beginning of his speech Stefan Meller (who did not belong to any party), the foreign minister in the new government formed by the Law and Justice, referred to the achievements of the previous governments in foreign policy that allowed Poland to be rooted on two pillars - NATO and the EU. A new element was the issue of energy security in the context of trying to affect the EU partners and the USA in this regard. The minister planned to create an interesting "comprehensive - preferably within the whole western system - energy security strategy and to integrate Poland into its implementation" (Meller, 2006). He assumed the need for rapid economic development that would bring the standard of living similar to the one in the countries of western Europe but this would have to be proceeded by making up civilization delays. Counteracting the huge economic competition would give economic security. This would help to raise the status of the state and run an effective policy. The minister connected this aspect with the need for finding a strategy towards the EU to achieve goals in three main areas: civilization development, "the need for broadly understood security", taking into account the transatlantic dimension and the role of the United States, and strengthening Poland's position as a solid and credible member of the EU. He also declared Poland's support for the extension of the Common Foreign and Security Policy. NATO was the foundation for Poland's security, and the CFSP was to be closely coordinated with NATO activities. The minister perceived tightening ties with the United States as an element that would enhance security and good relations within NATO. He was aware that only the cooperation of all countries in the West would counteract various threats, and that "our security depended on it" (ibid.).

In the following year Anna Fotyga, who became the foreign minister after Stefan Meller's resignation in April 2006 caused by the entry of the Self-Defence Party and Polish Family League to the government, gave an extended speech. Speaking of changes in foreign policy, she emphasised the need to ensure security and higher international prestige of Poland. She stated that "the main goal of Poland's foreign policy now and in the years to come until the goal is achieved, is the final confirmation of Poland's security, including energy security, as it is a new element of the security system" (Fotyga, 2007) [highlighted by the author]. On the energy side the minister assumed a common EU policy in relations with Russia which would lead to a new agreement with Russia to guarantee the security of energy resources supplies. In addition, Poland intended to diversify energy resources, therefore it declared its participation in the construction of the pipeline with Norway, Denmark and Sweden and the construction of a LNG terminal in Świnoujście. The minister called energy security as "the flagship of Poland's foreign policy" (ibid.). According to the minister it was Poland's great success that the final declaration of the 2006 Riga Summit on Energy Security included a paragraph on energy security, as, in her opinion, it made the Alliance consider energy security to be part of global security. In the whole speech energy security was shown as the leading element of foreign policy and a number of the policy directions were presented in relation to it (relations within the EU, Middle East, Persian Gulf). Even relations with Latvia and Estonia served this purpose. With Lithuania, Poland was to build a power plant in Ignalina, build power connections 
between the two countries and work on the refinery in Możejki. The presence in NATO was an essential element for the security of the state. Maintaining American involvement in Europe provided stability and security. This also included the question of constructing the missile defence shield and the need to take into account Poland's security postulates. The government note sent to the US government stated that it was necessary to increase Poland's security with the installation of the shield. Operations with Polish involvement in Iraq, Afghanistan, UN missions in Lebanon and the Golan Heights helped to eliminate the world's security threats at an early stage. An interesting thing was the declaration on giving great importance to the human dimension of security policy, strengthening democracy and respecting human rights in the world through providing resources for humanitarian and development aid (Europe, Lebanon, Iraq, Afghanistan, Africa). This policy was intended to create security on the continents. In addition, definitive legal regulations in relations with Germany would stabilize Poles' sense of security in solving the problem of German property, and within the framework of the Weimar Triangle, it suggested cooperation between defence ministries at the ESDP (cf. Kuźniar, 2014).

In 2007 snap parliamentary elections were held, in which the Law and Justice lost. In the speeches given by Law and Justice ministers one can easily notice some differences. The first one is more conciliatory and it emphasized global problems. Stefan Meller presented interesting ideas for the functioning of the EU and improving international security in the almost empty parliamentary hall. However, Minister Fotyga focused heavily on the issue of energy security (also present in Minister Meller's speech), which at the time was connected with the construction of the Nord Stream gas pipeline violating Polish interests. The agreement between Germany and Russia, without Poland's participation, was considered a long-term threat to its security. It was Radosław Sikorski, the Minister of National Defence in the Law and Justice government who compared this investment to another Ribbentrop-Molotov pact. ${ }^{3}$ Problems with the identity of the EU resulting from the difficult accession process of twelve new members, the failure of the ratification of the Constitution for Europe in France and the Netherlands, and the lack of a Community agreement on the future of energy security affected Polish foreign policy and the speech content because these factors were directly connected with the overall security of the state.

\section{"SECURITY" IN ANNUAL SPEECHES BETWEEN 2008-2015}

After the parliamentary elections in autumn 2007, the Civic Platform and Polish People's Party formed a government with Radosław Sikorski as the foreign minister. His work deserves a separate section due to the period of his office and the number of annual speeches he gave. One could try to determine whether there was a comprehensive approach to security issues in his speeches or whether security was a signifi-

${ }^{3}$ In 2015 he tweeted that the opposition to this investment was a mistake, because if we were not able to block it, and we were offered to have a board member and the pipeline going through the territory of Poland, we should have accepted it. See: Sikorski: PiS sprzeciwit się Nord Stream, a mógt się przyłaczyć, http://biznesalert.pl/sikorski-pis-sprzeciwial-sie-nord-stream-a-mogl-sie-przylaczyc/ (18.02.2017). 
cant issue for him. However, his annual speeches will be analysed chronologically in reference to the governments in which he was the foreign minister (2007-2011 and 2011-2014).

In 2008 the minister perceived Poland's presence in the EU and NATO as the bases of the state security. He hoped that after the ratification of the Lisbon Treaty the Common Foreign and Security Policy would strengthen. The other priority of the foreign policy was, in his opinion, Poland's stronger role in the global security system. He discussed the need for a reform of NATO so that it would be able to respond effectively to new challenges such as asymmetric conflicts. He strongly believed in the strategic partnership with the US and cooperation with the EU: "We do not want to choose, we want to have two complementary insurance policies" (Sikorski, 2008). He supported the development of ESDP, and the works on changes to the European Security Strategy. He declared Poland's support for international cooperation to halt the proliferation of mass destruction weapons and the will to find ways to overcome the OSCE crisis. Energy security was of special importance for which the minister expected support and the coordination of the EU policy under the Lisbon Treaty in order not to succumb to the blackmail of non-EU suppliers (mainly Russia). This would foster connections between the EU members.

An interesting thing was that the minister declared support for combating nonmilitary threats to security (international organized crime, smuggling, arms and drugs trafficking, human trafficking) and climate change (ecological security), with a special role to be played by the reformed UN. In order to create a good international climate in terms of security in the immediate vicinity of Poland, he called for an increase in development aid (ibid.).

It should be noted that the new Polish government made security issues an important element of its foreign policy. With respect to the international situation, the minister intended to continue the efforts to develop the EU energy security strategy to counter individual bilateral or multilateral agreements between the EU members and Russia. At that time, Germany, France, the Netherlands, Italy became economically closer to Putin's Russia and the energy sector played a key role in it.

In the subsequent years of the first government formed by the Civic Platform and the Polish People's Party security was a very important issue. The minister called for constant striving for its maintenance, since it was not given once and for all. He emphasised having one common voice on energy security with the EU partners. He perceived the crisis in the ratification of the Lisbon Treaty as a threat because the Treaty was needed to strengthen the EU political dimension and solidarity, and to broaden integration in foreign and security policy. "We already know that in the turbulent waters of global politics and economy it is safer not to sail in a national lifeboat but in the European liner" (Sikorski, 2009). In his opinion, the security of Poland was based on three pillars: NATO, the EU building its defence capabilities, and bilateral relations with the United States. He expressed a similar opinion in 2010 (Sikorski, 2010). It was the NATO membership that had brought the most benefits for security. Throughout his term Sikorski was striving for an ambitious EU security policy on energy supplies. Poland's accession to the Schengen area resulted in greater concern about the border security. The murder of a Polish geologist in Pakistan or the evacuation of Poles from 
Iraq, Georgia and the Gaza Strip revealed that "accepting responsibility for global security also carries risks" (Sikorski, 2009).

In 2010, the mission of Polish foreign policy was to provide favourable international conditions for security. Of the five priorities prepared for the Polish Presidency in the EU in 2011, three were related to this aspect: relations with the Eastern European states - creating proper political situation, building alliances to maintain security through the functioning of buffer states like Belarus and Ukraine, attracting Moldavia to the community; energy policy and energy security of the $\mathbf{E} \mathbf{U}$ - an area of increased engagement of Polish diplomacy over the years, present in every annual speech since 2006 as a very important aspect of foreign policy; European Security and Defence Policy $^{4}$ - Poland supporting every European project on the organization of collective defence and cooperation of numerous entities in the creation of the security zone.

The Minister also presented an interesting view on the activities of the OSCE. "As a structure, [...] from Vancouver to Vladivostok it is predisposed to serve as a forum for debate on the future of European security. This debate should cover all aspects of 'hard' and 'soft' security and cannot be taken away from assessing the fulfilment of internationally adopted commitments by the members of the organization. This applies, among other things, to the issue of conventional disarmament" (Sikorski, 2010).

The speech given in 2011, which was a kind of a summary, described raising the security of Poland as an element perceptible for the citizens. Poland was supposed to follow the path that had previously been taken by Spain or Turkey, namely the reconstruction of the old (historic) prestige as a serious and prosperous state. As he stressed, the mission of the Ministry of Foreign Affairs, defined by the employees, was "the realization of the interests of the Republic of Poland through cooperation in Europe and in the world for security, democracy and development" (Sikorski, 2011). Security was supposed to be the priority of the Polish Presidency of the EU in the second half of the year. In the speech the minister explained the notion of secure Europe - it was supposed to manage at the time of crisis and cooperate with NATO on defence issues, with stronger defence identity and real strength behind diplomacy. Additionally, energy security was to be achieved through the guarantee of energy supplies for all the members. Poland was also concerned about food security - mentioned only once in the period analysed in this article, but this aspect was only mentioned and the minister did not develop it. He emphasized that during his office Poland had built its credibility in the area of security, and Poland's postulates were included in the new NATO Strategic Concept. These included the "open door policy" for Georgia and Ukraine, the new missile defence system and plans for the deployment of nuclear weapons in Europe. He pointed to works aimed at denying the division to the old and new members, and the need for an equal distribution of infrastructure between Western Europe and Central East Europe, as both deserved the same level of security. He mentioned NATO's contingency plans for Poland and the Baltic States. ${ }^{5}$

${ }^{4}$ Further on it is abbreviated as ESDP.

5 The plan was called Eagle Guardian and it was to protect four states against Russian attack. It was created in 2009-2010. Nine divisions would be involved in military operations: American, British, German and Polish, and the NATO navy would operate from ports in Poland and Germany. Actions to implement the plan were taken by Radosław Sikorski after Russian-Belarusian military 
It is noticeable that in his first term Minister Sikorski often addressed the security issues. He discussed them mainly in the international aspect and in the context of creating a cover for Poland. He also raised energy issues, which became particularly important with the beginning of the construction of the Nord Stream gas pipeline as it hit directly Poland's energy security.

At the beginning of his second term for the next government, formed by the Civic Platform and Polish People's Party, minister Sikorski declared that he recognized as his "job as the head of Polish diplomacy to conduct Poland's foreign policy in a way that it should contribute significantly to improving our security and growth" (Sikorski, 2012). He noted that the Polish Army was responsible for the security of Poland and NATO was responsible for international security. He pointed out that after the experience of the Polish Presidency, the ESDP could not be implemented by 27 countries and only the co-operation of the states that wished to be involved should be supported. By analysing the possible scenarios for the EU, he predicted that if the disintegration of the Community occurred, Poland would be "deprived of a permanent basis of security." The speech was complemented by the twenty-nine-page document attached thereto Priorities of Polish Foreign Policy 2012-2016 (Priorytety, 2012), which addressed aspects of security in a very detailed way. The adoption of a four-year strategy could be seen as a manifestation of the government's awareness of planning objectives in foreign policy - although the law (Ustawa, 1997) obliges the foreign minister to prepare the strategy, this was the first and so far the only attempt after 1997, which referred to the sensitive area of state security. It contained numerous sections on security, including international security, energy aspects (especially in the context of Poland's policy towards the EU) or climate protection. Apart from analysing a number of processes, the document contained a separate three-page section titled 'Security', which, given the brief, synthetic nature of the document, proves how important it was for the foreign minister.

In the following year Minister Sikorski spoke about the benefits of the freedom of activity of one generation of Poles to achieve the "safe development" (of Poland), which was supposed to allow Poland to catch up with the West. He saw Poland's (European) security and the power of western civilisation in the European integration. In terms of security, Poland was to cooperate with the USA. A new element was the idea of intensified security dialogue with Sweden. He noted that historically in the struggle to guarantee security, also in the military aspect, Poland had been confined only to itself. He confirmed the guarantees given through NATO membership. The ESDP was supposed to be developed, but without the illusion that within a decade it would be able to take over the Alliance's tasks. Moreover, the Foreign Service Inspectorate was created for citizens' security (Sikorski, 2013).

In the last year of his office the minister again emphasized the importance of NATO for Poland's security. Owing to the crisis in Ukraine (which started more than two months before the annual speech), the Alliance's activities to secure Poland were implemented. He emphasized that the EU's military integration would give Poland greater security. He advocated strengthening the energy security of the EU neighbours, including Ukraine

exercises in 2009 called „Zapad” in 2009, see Eagle guardian, http://www.globalsecurity.org/military/ops/eagle-guardian.htm (19.02.2017). 
and Moldova. He perceived the elections to the European Parliament as a chance to develop the process of European integration (following the strategy: the more integration the greater security). After the events in Ukraine, Poland should try to join the euro zone, which would increase its security in the political sphere. Increased relations with Latvia and Estonia were also intended to serve this purpose (Sikorski, 2014).

With the change of Prime Minister - in November 2014 Ewa Kopacz replaced Donald Tusk, Grzegorz Schetyna became the new foreign minister. Since there cannot be two annual speeches given in one year, Schetyna presented the Information of the Council of Ministers on foreign policy tasks for the years 2014-2015, and after six months he gave the traditional annual speech (cf. Schetyna, 2014; Schetyna, 2015). Like his predecessor, he presented elements of state security guarantees that were typical for the governments formed by the Civic Platform and Polish People's Party. Schetyna was the foreign minister at the time of sanctions against Russia and the ongoing crisis in Ukraine, which directly affected the security of Poland and influenced the Minister's statements, and caused the emotional tone of his speech. He pointed to the lack of solidarity mechanisms to protect the EU from energy blackmail. He perceived the presence of NATO's individual troops in Poland as the strategy of preventing being a second category member of NATO and as an element of the securitization of Poland. After ten years of being an EU member, he saw Poland as a state striving for financial security and responsible for the Community. In his opinion the possible accession to the euro zone would bring not only economic or political benefits but it would also increase the state security, as the euro zone is strictly governed by the „one for all, all for one" principle. Good relations with Latvia and Estonia also resulted from common concern for security in the region. In his opinion, Europe had been in the most difficult situation since the fall of communism, but Poland was expected to undertake activities that would restore a sense of security on the continent. In general, Schetyna devoted nearly all his speech to security issues and stable, democratic Ukraine was "an important element of the European order and security built after the political transformation of 1989-1991" (Schetyna, 2014).

In the following year Schetyna described security and development opportunities as two goods guaranteed to all Polish citizens by foreign policy. Poland's foreign policy was also to be part of the ESDP. He presented security as crucial for Poland and Europe. As usual at times difficult for the future of Poland and the continent, the minister referred to the functioning of NATO, which, after the annexation of Crimea, began to protect the so-called "eastern flank", and for he minister it was important to strengthen the US engagement and to have Barack Obama's security guarantees for Europe. Schetyna stated that one cannot imagine permanent security on the continent without referring to the 1975 CSCE Final Act. Another challenge for the EU security was the situation in the Middle East and the Mediterranean. Islam fundamentalists would also constitute a threat to the internal situation of the Union. He returned to the need for a Community Energy Union project (Schetyna, 2015).

The two ministers worked in specific political conditions connected with the crisis, which undermined the economic security of some EU countries and, on the other, they had to deal with the consequences of closer energy cooperation between Russia and some Western states, which was against the interests of Poland. The consequences 
of the Arab Spring, the war in Ukraine and the refugee crisis in Europe in 2015 were a real challenge as they had a great impact on the sense of security but also strained the capacity of the Community and provoked a series of misunderstandings that led to the crisis of European integration, doubts in the sense of the EU and the rise of criticism in individual member states, and this had a significant impact on the sense of security in Poland.

\section{"SECURITY" IN ANNUAL SPEECHES BETWEEN 2016-2017}

The government change in Poland after the parliamentary elections in 2015 led to a partial evolution in foreign policy, especially in the rhetorical, declarative layer. The new minister - Witold Waszczykowski gave his annual speech very soon at the end of January 2016 (Waszczykowski, 2016). If one was to give it a formal title, it could be 'Security first'. The term itself was used in various contexts forty-four times (in 2017 thirty-nine times). The minister diagnosed a number of threats to international security. He made the primacy of international law over the brutal force one of the four prerequisites for Poland's entire foreign policy and he regarded breaking the law as a direct cause of the division into a world in which the powers dictated the smaller what to do. The approval of such policy would be a deadly threat to Poland, as it would allow the world, for example, to tolerate Russia's further political disintegration efforts in Central and Eastern Europe. Therefore, Poland was supposed to support the UN, the OSCE and the Council of Europe. The foreign policy vision of the new government on security was aimed at international security, building Poland's stance on the EU crisis (security crisis, neighbourhood crisis and European project crisis), to which diplomacy had to react. In 2016 Waszczykowski called Britain Poland's strategic European partner on security, which was widely criticized after the Brexit referendum. Despite that in 2017 the minister emphasised the importance of the bilateral contacts, also in terms of security.

Both his speeches focused on the search for security. In 2017 he stated that "in the 21 st century security becomes a common good of all mankind" (Waszczykowski, 2017), as crises erupting far from Poland and Europe reach them quickly. In his opinion, 12 months after the new government had come to power Poland became „more secure". Despite the subjective approach to Polish interests, he declared his concern about the security of Europe's borders. According to the minister, year 2016 improved the international security of Poland thanks to the provisions of the NATO summit in Warsaw. He stressed the need for Poland's temporary membership in the United Nations Security Council for 2018-2019 because this organisation was given by the international community "the right and duty to defend peace and security in the world" (ibid.). In his opinion, the security of Central Europe was largely guaranteed by American forces. He regarded the transatlantic cooperation to be a key to security. He also emphasised the trust of allies from the region, which, in his opinion, appreciated Poland's concern about the security of all cooperating states, including Bucharest's Nine. Moreover, Poland opted for the creation of Trimarium - the region between the Baltic, the Adriatic and the Black Sea (cf. Michat, 2016; Roman, 2016), whose common ob- 
jective would be reaching the West European level of civilization development and 'security comfort'. The Minister saw in it great chances for the cooperation between the twelve countries in the group (Visegrad Group, 3 Baltic states, Romania, Bulgaria, Austria, Croatia and Slovenia).

Waszczykowski emphasized that Poland was presented in NATO as a model because it allocated $2 \%$ GDP to the army, and at least $20 \%$ of this amount was spent on the modernization of the armed forces. He also claimed that the NATO-EU cooperation should be of particular importance, especially in terms of the fight against terrorism and hybrid threats, cyber security, military exercises and the support for the members' resistance (Russian pressure). Additionally, he found it necessary to develop cooperation within the ESDP.

In the vision presented by Minister Waszczykowski, Poland's foreign policy focused on numerous aspects of security, of which the international situation and uncertainty about the future of Europe and the EU's neighbourhoods meant that a number of his diplomacy activities were oriented towards building alliances, strengthening bilateral and multilateral relations, creating new formats of collaboration like Trimarium. From the point of view of the analysed research problem, his speeches are the most visible expression of the influence of the international situation on the security issues, though it should not be forgotten that for the Law and Justice party the state security and ensuring the diversification of energy supplies have always been the highest priority declared with great determination.

\section{$* * *$}

Security has been a very important element and foundation of foreign policy since the beginning of system changes in Poland. It became even more important in the 21 st century due to the international situation, Poland's increasing involvement in solving international problems, its involvement in allied actions (Iraq, Afghanistan), greater political opportunities after the EU and NATO accession, and the need to meet the requirements of the developing economy (gas, oil). Apart from the traditional orientation in the area of physical security of the state, energy security became an important aspect because of the inability to obtain self-sufficiency in this area. It became even more important after the decision to build the Nord Stream gas pipeline by Germany and Russia (the Dutch company N.V. Nederlandse Gasunie joined the consortium in 2010) and it has been visible in the speeches of all ministers since 2006. It is worth noting that energy security was not addressed by the government formed by the Democratic Left Alliance, despite withdrawing from the agreement with Norway and Denmark and signing the gas supply agreement with Russia - recognized by the Supreme Chamber of Control as negative for the state interest (Informacja o wynikach, 2004). In 2004 Minister Cimoszewicz only noted that energy dialogue was necessary in relations with Russia (Cimoszewicz, 2004). After 2005 the EU solidarity on energy issues was officially expected. It was generally believed that from the history perspective the cooperation of Russia and Germany in different fields was a threat to Poland and against its long-term interests, but despite that the criticism was quite mild. 
It should be noted that for all Poland's foreign ministers after 2001, and in earlier years, efforts to provide the state security in various contexts (energy, public, food or economic) were generally the most important elements of their annual speeches. It was said directly or in the extended form when developing on Poland's NATO/EU presence, the need for the strategic partnership with the US and cooperation with the neighbours. In these contexts, there were always statements on actions aimed at supporting, tightening or developing Poland's security with the full awareness of each minister that there was a cross-party need for taking care of it. It is also significant that there were also references to securing the activities of Polish diplomatic missions, which is the statutory task of the Minister of Foreign Affairs (cf. Sikorski, 2014; Waszczykowski, 2017).

The above analysis leads to the conclusion that the international situation played a significant role as an inspiration factor for ensuring security to Poland, though this process was also carried out continuously, without stimulating factors. Certain events in the world or in the immediate vicinity of Poland influenced the language of the debate (for example a hard-hitting speech by Radosław Sikorski in 2014), emphasizing the validity of decisions taken in the past (joining the EU, NATO), declaring to maintain policy direction, maintaining an appropriate level of relations with the USA. Sometimes, as in the case of the ESDP, following the experience of Poland's presidency in the second half of 2011, the evident weakness of the EU as a whole in terms of security made the minister doubt about the readiness to pursue its tasks (Sikorski, 2012), which should be considered a desirable reflection of particular importance, given the fact that he ESDP was one of the priorities of Polish Presidency of the EU (tactically justified), and Poland hoped to develop common standards for the EU countries.

A significant event that directly forced the ministers to respond was the Russian invasion of Crimea, because it occurred in a country bordering with Poland, whose existence had been of fundamental importance for the future of Poland and its security for years, according to Polish political elites. Indeed, since this event the analyses of all the ministers have been focused on international security and direct threat to its functioning and to the existence of Poland. Fear of the consequences of Russia's further actions was noticeable in the speeches of Radosław Sikorski, Grzegorz Schetyna and Witold Waszczykowski. It is significant that the annexation of Crimea was an influence factor of the international situation on the security of Poland, as it helped to mobilize NATO allies to develop the infrastructure and deploy military forces in Poland and Eastern Europe, despite the conservative and inconsistent foreign policy of President Barack Obama (Walt, 2017). The assessment of the extent and involvement in resolving the problem in Ukraine by Radosław Sikorski, Grzegorz Schetyna and Witold Waszczykowski goes beyond the scope of this publication, but from the point of view of the article some parts of their speeches and contexts are relevant. They focused on stressing the need for Ukraine's statehood, and at the same time they opted for the structural reforms there, even assuming the possibility of a possible rearmament if the local war was continued (Schetyna, 2015). Well managed and organized Ukraine - supported by Poland, would secure Poland's eastern border and stabilize the political situation in Central Europe, and this was much more important than immediate benefits or reciprocal animosity. 
Over the years NATO's commitment to the security of Poland has been strengthened but it resulted from the international situation rather than a greater reflection within the Alliance. Moreover, the LNG terminal in Świnoujście has been built and the LNG terminal in Gdańsk has been developed as part of energy security. However, the ministers have not been successful in influencing on the EU's regulations in the energy sector, which results directly from the often conflicting interests of Poland and Germany and Poland's limited position in the EU structures. The ministers rarely referred to ecological security, which was related to the participation of coal in modern energy and the problem of Poland's dependence on coal and being one of the most polluting states in the EU. The low awareness of the significance of the problem can also be seen through the phenomenon of the national problem of smog that appeared at the end of 2016 and the beginning of 2017.

Summing up, one can wonder whether Poland will have a foreign minister who will be able to state that Poland is secure or will not have to analyse in the annual speech the level of security in Poland's closer and further surroundings. It is difficult not to get an impression that the political situation in Eastern Europe and the Middle East proves there is no chance for that. On the other hand, ensuring state security is a permanent phenomenon resulting from the limited international position of Poland, and individual ministers can only be described as inadequately or insufficiently involved in the process. The public affirmation that we are secure in the broad sense of the word, and nothing constitutes a threat to Poland, would mean the beginning of losing the sense of security. As the Latin proverb says, "If you want peace, get ready for war."

\section{BIBLIOGRAPHY}

Barber B. R. (2005), Imperium strachu. Wojna, terroryzm i demokracja, Warszawa.

Bartoszewski W. (2001), Informacja ministra spraw zagranicznych o podstawowych kierunkach polityki zagranicznej Polski, Warszawa, 6.06.2001.

Bezpieczeństwo (2017), http://sjp.pwn.pl/szukaj/bezpiecze\%C5\%84stwo.html (28.03.2017).

Buzan B. (1997), Rethinking Security after the Cold War, "Cooperation and Conflict", Vol. 32 (1).

Cimoszewicz W. (2002), Informacja ministra spraw zagranicznych o podstawowych kierunkach polityki zagranicznej Polski, Warszawa, 14.03.2002.

Cimoszewicz (2003), Informacja Rzqdu na temat polskiej polityki zagranicznej w 2003 roku, Warszawa, 22.01.2003.

Cimoszewicz W. (2004), Informacja ministra spraw zagranicznych o zadaniach polskiej polityki zagranicznej w 2004 roku, Warszawa, 21.01.2004.

Fotyga A. (2007), Informacja na temat polskiej polityki zagranicznej w 2007 roku, Warszawa, 11.05.2007.

Informacja o wynikach kontroli zaopatrzenia $w$ gaz ziemny (2004), Najwyższa Izba Kontroli, Warszawa.

Koziej S. (2011), Bezpieczeństwo: istota, podstawowe kategorie $i$ historyczna ewolucja, "Bezpieczeństwo Narodowe", No. II.

Kuźniar R. (2014), Wzlot i upadek Europejskiej Polityki Bezpieczeństwa i Obrony, "Bezpieczeństwo Narodowe", No. IV. 
Łastawski K. (2017), Dylematy wspótczesnej polskiej racji stanu, in: Polityka zagraniczna Polski $w$ zmieniajacym się tadzie międzynarodowym: wybrane problemy, (eds.) R. Zięba, T. Pawłuszko, Kielce.

Meller S. (2006), Informacja Ministra Spraw Zagranicznych o z zadaniach polskiej polityki zagranicznej w $2006 r$., Warszawa, 15.02.2006.

Michat Kobosko: Koncepcja Trójmorza ma sens (2016), http://www.rp.pl/Publicystyka/312159879Michal-Kobosko-Koncepcja-Trojmorza-ma-sens.html\#ap-3 (27.03.2017).

Priorytety polskiej polityki zagranicznej 2012-2016 (2015), Warszawa.

Roman Kuźniar: Orwell, witaj w domu (2016), http://www.rp.pl/Publicystyka/311219885-RomanKuzniar-Orwell-witaj-w-domu.html\#ap-1 (27.03.2017)

Rotfeld A. D. (2005), Informacja Ministra Spraw Zagranicznych o zadaniach polskiej polityki zagranicznej w 2005 r., Warszawa, 21.01.2005.

Rumsfeld: New Tools Needed Against Threats (2003), http://www.iwar.org.uk/news-archive/2003/06-13-4.htm (25.03.2017).

Schetyna G. (2014), Informacja Rady Ministrów o zadaniach polskiej polityki zagranicznej w latach 2014-2015, Warszawa, 6.11.2014.

Schetyna G. (2015), Informacja Ministra Spraw Zagranicznych o zadaniach polskiej polityki zagranicznej w 2015 roku, Warszawa, 23.04.2015.

Sikorski R. (2008), Informacja Ministra Spraw Zagranicznych na temat polityki zagranicznej RP w 2008 roku, Warszawa, 7.05.2008.

Sikorski R. (2009), Informacja Ministra Spraw Zagranicznych na temat polityki zagranicznej RP w 2009 roku, Warszawa, 13.02.2009.

Sikorski R. (2010), Informacja Ministra Spraw Zagranicznych na temat polityki zagranicznej RP w 2010 roku, Warszawa, 8.04.2010.

Sikorski R. (2011), Informacja Ministra Spraw Zagranicznych nt. polityki zagranicznej RP w 2011 roku, Warszawa, 16.03.2011.

Sikorski R. (2012), Informacja Ministra Spraw Zagranicznych na temat polityki zagranicznej RP w 2012 roku, Warszawa, 29.03.2012.

Sikorski R. (2013), Informacja Ministra Spraw Zagranicznych na temat polityki zagranicznej RP w 2013 roku, Warszawa, 20.03.2013.

Sikorski R. (2014), Informacja Ministra Spraw Zagranicznych na temat polityki zagranicznej RP w 2014 roku, Warszawa, 8.05.2014.

Statement by H.E. Dr. Wlodzimierz Cimoszewicz, Minister for Foreign Affairs of the Republic of Poland at the Fifty-Seventh Session of the General Assembly of the United Nations, New York, 15.09.2002 (2002), http://www.un.org/webcast/ga/57/statements/020915polandE.htm (20.03.2017).

Traktat Pótnocnoatlantycki sporzadzony w Waszyngtonie dnia 4 kwietnia 1949 r. (2014), „Bezpieczeństwo Narodowe”, No. I.

Ustawa o działach administracji rzqdowej (1997), Official Journal, No. 141, item 943.

Walt S. M. (2017), Barack Obama Was a Foreign-Policy Failure, http://foreignpolicy.com/2017/01/18/ barack-obama-was-a-foreign-policy-failure/ (20.03.2017).

Waltz K. N. (2000), Structural Realism after the Cold War, „International Security”, Vol. 25, No. 1 (Summer).

Waszczykowski W. (2016), Informacja Ministra Spraw Zagranicznych o zadaniach polskiej polityki zagranicznej w 2016 r., Warszawa, 29.01.2016.

Waszczykowski W. (2017), Informacja Ministra Spraw Zagranicznych o zadaniach polskiej polityki zagranicznej w 2017 roku, Warszawa. 


\begin{abstract}
After the WTC attacks in 2001, the international situation and security in the world has changed. The United States and its allies - including Poland - have started a war against global terrorism and got involved in the war in Afghanistan and Iraq. The economic crisis at the end of the first decade of the $21^{\text {st }}$ century, the Arab Spring, the rise of the so-called Islamic State, the war in Ukraine and the refugee crisis have affected the state of security in Poland and in Europe. Since 2014 Poland's foreign ministers have been forced to react to the most difficult geostrategic situation after 1989. The paper analyses the issue of security in the annual speeches of Poland's foreign ministers. The research problem is the impact of the international situation on the contents of the ministers' annual speeches in this regard.
\end{abstract}

Keywords: exposé, security, international security, foreign affairs, WTC

\title{
POJĘCIE „BEZPIECZEŃSTWO” W EXPOSÉ MINISTRÓW SPRAW ZAGRANICZNYCH RP PO 2001 ROKU
}

\section{STRESZCZENIE}

Wraz z zamachami na WTC w 2001 roku sytuacja międzynarodowa i stan bezpieczeństwa na świecie zmieniły się. Stany Zjednoczone wraz z sojusznikami - w tym z Polską, rozpoczęły wojnę ze światowym terroryzmem i zaangażowały się w wojny w Afganistanie i w Iraku. Kryzys ekonomiczny z końca pierwszej dekady XXI w. na świecie, „Arabska Wiosna”, powstanie tzw. Państwa Islamskiego, wojna na Ukrainie i kryzys uchodźczy oddziaływały na stan bezpieczeństwa w Polsce i w Europie. Od 2014 roku polscy ministrowie spraw zagranicznych zmuszeni są reagować na najtrudniejszą sytuację geostrategiczną od 1989 roku. W artykule analizie poddane zostało zagadnienie bezpieczeństwa w exposé ministrów spraw zagranicznych Polski. Problem badawczy to wpływ sytuacji międzynarodowej na treści exposé poszczególnych ministrów w tym aspekcie.

Słowa kluczowe: exposé, bezpieczeństwo, bezpieczeństwo międzynarodowe, polityka zagraniczna Polski, WTC 